\title{
Introduction: The Next Wave of Enlargement: The European Union and Southeast Europe after 2004
}

\section{GRAHAM TIMMINS AND DEJAN JOVIĆ}

The completion of the Central and Eastern European accession process into the European Union (EU) in 2004 can in broad terms be taken to have been a considerable success in generating an enlarged European zone of peace and stability. But the experience of post-communist transformation within this region is in stark contrast to that in South East Europe where the collapse of the Yugoslav Federation at the end of the Cold War unleashed a bloody and devastating conflict which necessitated the military engagement of the international community and culminated in a NATO-led military intervention into Kosovo in 1999. Although the EU has aspirations to develop a military dimension to its external identity, its international presence continues to be articulated predominantly through soft power e.g. diplomatic, economic and normative foreign policy instruments. The next wave of EU enlargement - if and when it happens - therefore represents a crucial contribution both to the continued creation of a stable European Order and the credibility of the EU as an effective international actor.

The then still European Community (EC) had demonstrated a high degree of misplaced confidence at the start of the 1990s in relation to responsibility for managing the emerging crisis in the Balkans when Jacques Poos, the Luxembourg Foreign Minister speaking on behalf of the European Council Presidency, announced in 1991 that 'the hour of Europe has dawned'. ${ }^{1}$ This statement had come at a time when the EC was negotiating the Treaty on European Union and which would lead to the creation of a Common Foreign and Security Policy (CFSP). By the end of the decade and in light of Kosovo, the EU's ability to manage conflict in its own backyard had been exposed as a myth and Europe's continued reliance upon a US military presence was clear for all to see. Lessons have been learned. The European Security and Defence Policy (ESDP) established at the Cologne European Council summit in June 1999 acknowledged the need to develop an autonomous military

\footnotetext{
${ }^{1}$ See Timothy Garton Ash, History of the Present: Essays, Sketches and Despatches from Europe in the 1990s, London: Penguin, 1999, p.211.
} 
capacity to support its international presence and the policy of common strategies agreed two years previous at the Amsterdam European Council summit in June 1997 recognised the need for greater coherence in EU foreign policy statements and the behaviour which flowed from them. The creation of a High Representative for the CFSP in 1999 as a means of coordinating the foreign policy positions of Member States was a further step forward in this direction as was the European Security Strategy published in December 2003 which highlighted the EU's collective understanding of global security challenges. ${ }^{2}$

Where the Western Balkans are specifically concerned, the EU plays an important role in peacekeeping and conflict prevention operations. In March 2003 the EU launched its first official peacekeeping mission, Operation Concordia, in Macedonia and this was followed by an EU Police mission, Operation Proxima, in December 2003. Of more significance was the announcement of Operation Althea in BosniaHerzegovina in July 2004 and commencement in December 2005 which transferred responsibility for peacekeeping activities from NATO to the EU. But if the EU's growing military and police presence in the region is designed to maintain the status quo, the forward-thinking strategy is represented by the EU's political strategy towards the region. Exempted in the main from EU assistance programmes for much of the 1990s, it was not until the cessation of military conflict that the EU began to channel assistance programmes towards the Western Balkans in earnest. The Stabilisation and Accession Process (SAp) launched at the Zagreb summit in November 2000 set out the ultimate goal of EU membership for the states within the Western Balkan region on condition that the 'Copenhagen criteria' of a 'stable democracy, respecting human rights, the rule of law, and the protection of minorities; a functioning market economy; and the adoption of the common rules, standards and policies that make up the body of EU law' be met in full. ${ }^{3}$ The SAp has been supported by CARDS (Community Assistance for Reconstruction, Development and Stabilisation) which has seen 4.6 billion Euro transferred to the region during 2000$2006 .^{4}$

\footnotetext{
${ }^{2}$ See http://ue.eu.int/cms3_fo/showPage.asp?id=261\&lang=EN for a general overview of the ESDP and the European Security Strategy.

${ }^{3}$ See http://europa.eu.int/comm/enlargement/enlargement.htm (accessed 16 December 2005).

${ }^{4}$ See http://europa.eu.int/comm/enlargement/cards/index_en.htm (accessed 16 December 2005).
} 
The EU's commitment to assisting in the preparation of the South East European states readiness for membership was reaffirmed at the Thessaloniki summit in June 2003 and included the initiative to establish bilateral European Partnership Agreements which would build upon the previously negotiated Stabilisation and Accession Agreements (SAA) and would target assistance towards the specific goal of integrating the region into the wider European political and economic Order. ${ }^{5}$

The report produced by the International Commission on the Balkans in April 2005 succinctly summarises the dilemma facing the region. Although the Western Balkans are now relatively stable, the states within them remain weak and continue to experience low or negative economic growth, high unemployment and political corruption. Within the strategy of integration, the Commission concludes 'the question today is no longer "what should be done?" We should clearly bring the region into the EU. Rather we need to establish the sequence of policy steps to be undertaken and the structure of the incentives that will make them work. We need policies so that the region can get on, get in and catch with the rest of Europe'. ${ }^{6}$

But this agenda is far from controversial. Although integration for the Western Balkan region into the EU at the earliest opportunity is viewed in a positive light by the majority of observers, what is missing from the EU strategy is any firm commitment to a date by which the South East European states could anticipate membership. The frustration this omission provokes is reminiscent of the situation the Central and Eastern European states found themselves in during the early to mid-1990s and raises the danger of an emerging 'expectation gap' between the anticipated benefits of membership and the inability of the EU to deliver a firm commitment to accession. Furthermore, the intended 'Europe effect' or Europeanisation process fostered by the Copenhagen criteria are open to accusations of normative imperialism with the postmodern identity of the EU at odds with the process of post-communist nation building and prevalence of ethnic nationalism. Both issues run the risk of alienating electorates and the governments they elect from the EU unless a timetable can be produced which provides tangible hopes for entry at some point in the near to medium future.

\footnotetext{
${ }^{5}$ See http://europa.eu.int/comm/enlargement/see/gacthess.htm (accessed 16 December 2005).

${ }^{6}$ International Commission on the Balkans, The Balkans in Europe's Future, Sofia: Secretariat of the Centre for Liberal Strategies, 2005, p.9.
} 
Bulgaria and Romania remain hopeful of their entry in 2007 and the decision taken in October 2005 to commence accession negotiations with Turkey and Croatia open the door for Turkish membership from 2015 onwards and for Croatia in 2009. For the remaining states in the Western Balkans; Albania, Bosnia and Herzegovina, The former Yugoslav Republic of Macedonia (fYROM) and Serbia and Montenegro, the situation is less certain. The burden of meeting the Copenhagen criteria rests firmly upon the shoulders of the states in the region but the ability of the EU to absorb new member states is a factor which should not be underestimated. In this respect the prospects for an early entry of the South East European states into the EU were dealt a damaging blow with the failure of the Constitutional Treaty in 2005. The EU, already suffering from enlargement fatigue following the mammoth efforts to ensure the success of the Central and Eastern European enlargement in 2004, entered a 'pause for reflection' during the UK Presidency in the latter part of 2005 and it remains unclear whether there is sufficient political will to facilitate the necessary institutional and financial reform that would allow the EU to continue to expand its membership.

The next wave of enlargement thus represents a journey which is far from completion and in many ways is still at the beginning. Yet, it remains the strategic foreign policy objective for all countries in the region. In addition - and perhaps even more importantly - the prospective membership of the EU is now the main force behind domestic political and economic reforms in countries which have only recently left the wars and conflicts behind. Further stabilisation and democratisation of Bosnia and Herzegovina largely depends on success of transition from the initial 'Dayton' phase in which the peace and stability were the main priority, to the second - 'Brussels' phase in which the power will be gradually transferred from international supervisory bodies to democratically elected Bosnian institutions. The prospect of EU membership for Bosnia-Herzegovina is one of the main forces of cohesion and stability in this country today. In Serbia and Montenegro, the EU plays the role of an impartial arbiter in disputes between these two republics. Although the EU might yet be unable to prevent disintegration of this federation into two separate states, it is almost certain that neither of two republics will take decisive steps without considering possible consequences of separation (or re-integration) for the future of Serbian and Montenegrin relations with the EU. The EU is also directly involved in negotiations on final status of Kosovo. Similarly, its direct involvement in 
Macedonian crisis in 2001 resulted in the EU-drafted 'Ohrid Agreement', which restructured Macedonia as practically a bi-national state. Thus, despite initial failure to prevent wars and conflicts in the early 1990s, the EU is now playing a constructive role in the region. But, the key to this success is not in a threat of coercion, but in attractiveness of the reward it can (can it?) offer to all countries in the Western Balkans. If in the second half of the 1990s the 'stick' helped ending the wars in Bosnia-Herzegovina and Kosovo, in the first decade of the $21^{\text {st }}$ century the 'carrot' of full EU membership is more likely to secure stability and enhance democracy in the Western Balkans. The main price, the one that all countries of the region now desire, is - full membership of the EU. For the countries of the region, only the full membership of the EU can be seen as recognition of 'normality', i.e. as confirmation that the period of instability followed by (sometimes humiliating) international supervision over domestic policy processes is over. Political elites of the countries of Western Balkans - but also the large segment of the population - sees the membership as the end of a long and painful transition from the status of a disorderly and undesirable neighbour to status of an equal partner and a 'member of the club'. After centuries of various authoritarian (and even totalitarian) regimes sitting on the fence that divides 'Europe' and Others, the countries of the Western Balkans are now hoping to be offered a seat around the same table with all (most) other fellow Europeans - and thus to be treated as equal to everybody else.

However, with recent institutional crises and uncertainties over future size and shape of the European Union, the question remains: what if the EU could not deliver on its 'open doors' policy towards the countries of the Western Balkans? Among the officials on both sides (i.e. within the EU and in the countries concerned) there is a degree of denial that this could happen. Although cautiously avoiding to specify any date for entry of the countries of the Western Balkans into the European Union, in public the EU officials remain optimistic: sooner or later they will all become members. But, how convincing is this optimism in the view of difficulties that the European Union is facing internally? In the immediate aftermath of its 2004 enlargement, the European Union seems to be divided (perhaps more than ever before) over major policy issues - not only over further enlargement (especially with regard to Turkey), and its Constitutional Treaty, but also over the war in Iraq and relations with the United States. In this situation, there is a realistic danger that to an 
increasing number of people in the Western Balkans the EU loses some of its attractiveness. In addition, a new wave of anti-immigration rhetoric and recent successes of far-right parties in a number of EU countries could discourage liberal pro-European forces in countries of the Western Balkans. After all, the nationalist anti-European forces in all countries of the Western Balkans already compare the European Union with former Yugoslavia (and even with the former USSR), arguing that such a complex multi-ethnic political structures simply cannot survive. Internal crisis of the EU would therefore indirectly strengthen anti-European forces in the Western Balkans, which in turn could be damaging for the process of stabilisation and democratisation of the region. And vice versa, a more efficient European Union which remains committed to its policy of further enlargement and delivers upon it, will serve as the main force of stability and democracy in the Balkans. The future of the EU will have direct consequences for the stability of the Western Balkans - and if this stability is once again undermined, the European Union might find it even more difficult to manage it than it was fifteen years ago.

This special edition focusses on the next wave of enlargement of the European Union, which should include countries of the Western Balkans. It is based on contributions which emerged from a conference workshop hosted by the Department of Politics at the University of Stirling in March 2004 and which comprised a wide range of academic specialists and practitioners from EU Member States and South East Europe. David Phinnemore's contribution sets out the broad political debates surrounding the state of the EU enlargement debate in the aftermath of the 2004 enlargement and the failure of the Constitutional Treaty and this is followed by contributions from Dimitar Bechev and Paul G.Hare who focus on the political and economic conditions in South East Europe and the impact of EU policy. The final contributions come from Gülnur Aybet and Dejan Jović who provide evaluations of Turkey and Croatia, the evolution of their policies towards the EU and prospects for membership.

\section{Acknowledgements}

The workshop was facilitated by the generous financial support of the British Academy, Economist Intelligence Unit and the United Kingdom's Foreign and 
Commonwealth Office and their support is acknowledged with gratitude. On behalf of all concerned with this project, we wish to thank the editor of JSEB, Vassilis Fouskas, and Ms Emily Jones at Taylor and Francis for their support and assistance in the development of this special edition.

Graham Timmins is Head of Politics at the University of Stirling and Jean Monnet Professor in European Integration Studies.

Address for correspondence: Department of Politics, University of Stirling, Stirling FK9 4LA, Scotland UK. Email: graham.timmins@stir.ac.uk.

Dejan Jović is Lecturer in Politics at the University of Stirling. He is the author of Jugoslavija - država koja je odumrla, Prometej and Samizdat B92, Zagreb and Belgrade, 2003.

Address for correspondence: Department of Politics, University of Stirling, Stirling FK9 4LA, Scotland UK. Email: dejan.jovic@stir.ac.uk 